\title{
KRAKOWSKA KURTYNA HENRYKA SIEMIRADZKIEGO: ALEGORIE I REBUSY
}

\begin{abstract}
(...) pragnąc widzieć, lub raczej patrzeć, traci się jedność zamkniętego świata, odnajdując się w niewygodnym otwarciu płynnego odtąd uniwersum, wydanego na wszystkie podmuchy sensu; tutaj synteza stanie się krucha aż do rozpadu; a przedmiot oglądu, dotknięty przypadkowo przez odłamek rzeczywistego, oddzieli podmiot od wiedzy, powierzając rozum czemuś takiemu, jak rozdarcie.
\end{abstract}

Didi-Huberman 230

Krakowska kurtyna Henryka Siemiradzkiego ${ }^{1}$ (il. 1) wydaje się obrazem wewnętrznie sprzecznym. Obrazem, który został ufundowany na sprzecznościach i który te sprzeczności z wielką biegłością maskuje. Celem artykułu jest wskazanie kilku spośród pęknięć, miejsc, gdzie cała ta świetnie przemyślana i po mistrzowsku wykonana konstrukcja odsłania niepewne rusztowanie. Kurtyna Siemiradzkiego jest modelowym przykładem procesu racjonalizacji obrazu, przemieszczania obrazu na pozycję pojęcia, wypierania „obrazu płynnego", ale także jednym z tych ważnych miejsc, które stanowią punkt przejścia na drugą stronę wstęgi Möbiusa.

Henryk Siemiradzki (1843-1902), jeden z najsławniejszych polskich malarzy XIX wieku, a w wieku XX jeden z malarzy najbardziej gruntownie zapomnianych, znany jest przede wszystkim dzięki obrazom przedstawia-

Dr Agnieszka Kuczyńska - Katolicki Uniwersytet Lubelski Jana Pawła II, Wydział Nauk Humanistycznych, Instytut Nauk o Sztuce, Katedra Badań nad Sztuką od Starożytności do Współczesności; adres do korespondencji: Aleje Racławickie 14, 20-950 Lublin; e-mail: agnieszka. kuczynska@kul.pl; ORCID: https://orcid.org/0000-0002-4436-0038.

${ }^{1}$ Udział w pracach nad grantem Korpus dziet malarskich Henryka Siemiradzkiego MNiSW Narodowy Program Rozwoju Humanistyki (2015-2020) sprawił, że wiele lat po napisaniu doktoratu i opublikowaniu książki na temat kurtyn Henryka Siemiradzkiego (Kuczyńska) powróciłam do dawnego tematu. Spotkania z międzynarodowym zespołem specjalistów i poznanie niedostępnych wcześniej materiałów pozwoliło mi zobaczyć kurtyny Siemiradzkiego w nowej perspektywie. 
jącym sceny z życia w starożytnym Rzymie. Malowidła alegoryczne stanowią w jego twórczości stosunkowo nieliczną, chociaż ważną grupę prac. Oprócz dwóch kurtyn Teatrów Miejskich - Krakowa (1894) (il. 1) i Lwowa (1900) należą do niej plafony w pałacu Zawiszy w Warszawie (1882, zniszczony) i w pałacu Nieczajewa-Malcowa w Petersburgu (1886 i 1890), Apoteoza Kopernika dla Biblioteki Uniwersyteckiej (1891, zniszczony) i dekoracyjne panneaux dla Filharmonii w Warszawie (1901, zniszczone).

Malowane kurtyny teatralne jako szczególny rodzaj obrazu, różniący się od innych funkcją, techniką wykonania oraz projektowanym sposobem ekspozycji, zajmują w tej grupie specjalne miejsce. Przedmiotem analizy będzie kurtyna Teatru Miejskiego (obecnie Teatru im. Juliusza Słowackiego) w Krakowie, traktowana jako przykład szczególnej formuły malarstwa alegorycznego na swój sposób pokrewnej rebusom, które - jak świadczą liczne zachowane w szkicownikach przykłady - Siemiradzki z upodobaniem uprawiał.

$\mathrm{Z}$ technicznego punktu widzenia krakowska kurtyna jest jednym z największych obrazów Siemiradzkiego. W całości mierzy 11,94×9,60 m. Obraz centralny ma powierzchnię $78,35 \mathrm{~m}^{2}$. Figury na pierwszym planie są mniej więcej 1,5 raza wyższe od figur naturalnej wielkości. W takim formacie artysta, któremu pozostawiono wolną rękę co do wyboru tematu i sposobu jego realizacji (Boniecki 114), przedstawił swoje artystyczne Credo. W recenzjach pisano, że obydwie kurtyny Siemiradzkiego na dwa różne sposoby mówią o tym samym: „uplastyczniają” jego poglądy na „sztukę w ogólności” (Sarnecki 992).

W dniu inauguracji kurtyny na życzenie Siemiradzkiego dostępna była ilustrowana ulotka, która pozwalała zidentyfikować przedstawione figury (il. 2). Na rycinie każda postać jest oznaczona numerem. Poniżej zamieszczono stosowne objaśnienie. Na całość składają się cztery grupy figuralne:

A. Grupa środkowa: Natchnienie (1) kojarzy Piękno (2) z Prawdą (3).

B. Grupa z lewej strony: przed postacią Tragedii (4) roztacza się obraz niedoli i zbrodni. Widma (5) i Furie (6), uosabiające wyrzuty sumienia i zemstę, ścigają Morderstwo (7) i Występną Miłość (8). Eros (9) płacze nad urną z prochami drogiego serca. W głębi u stóp Sfinksa (10) (Przeznaczenia) pierwiastki Dobrego (11) i Zlego (12) walczą o panowanie nad światem.

C. Grupa na pierwszym planie: Komedia (13) przygląda się z uśmiechem uciesznym figurkom, którymi potrząsa przed nią Trefniś (14).

D. Grupa ze strony prawej: Psyche (15) (dusza) uwalnia się z więzów zmysłowości (16), usiłując za Muzyką (17) i Śpiewem (18) wznieść się ku niebu. W głębi grono Młodzieży (19) otacza w tańcu posąg Terpsychory (20). 
Logiczny układ alegorycznej sceny podkreśla symetryczna kompozycja, wpisana w podziały architektonicznej ramy. Wydaje się, że mamy przed sobą pokaz koherentności świata jako zhierarchizowanej, racjonalnej struktury. Jednocześnie barwny, wypełniony dekoracyjnymi detalami „żywy obraz” przykuwa uwagę materialną dosłownością przedstawionych postaci i przedmiotów.

W przypadku obydwu kurtyn Siemiradzki zdecydował się na wybór bardzo popularnej w tym czasie konwencji żywego obrazu. Namalował przedstawienie fikcyjnego przedstawienia. Wykonany $\mathrm{z}$ wielką biegłością techniczną iluzjonistyczny obraz jest jednocześnie zasłoną, która podnosząc się do góry, zdradza swój złudny charakter. W tym jednak momencie przed oczami widzów pojawia się kolejne przedstawienie, tym razem rozgrywające się na scenie teatru. Rzeczywistość jest wielowarstwowa i niejednoznaczna. Ontologiczny wymiar skonstruowanego w ten sposób obrazu jest wyjątkowo niejasny.

Na obydwu kurtynach znaleźć można motyw teatru w teatrze. Na kurtynie krakowskiej na pierwszym planie Komedia i Momos (bóstwo ironii) bawią się, pociągając za sznurki kukiełki - karykaturalne figury prawnika, rycerza, chorego $\mathrm{z}$ urojenia i pary $\mathrm{w}$ rokokowych strojach. Teatr marionetek powraca również na kurtynie lwowskiej. W prawym dolnym rogu płótna Komedia opiera się o teatrzyk opleciony różami i cierniami. Na szczycie tego teatrzyku znajduje się figura Sfinksa. Poniżej został umieszczony napis: Theatrum vanitatis. Risus. Lacrimae (Teatr marności. Śmiech. Łzy). W ten sposób skomentowany motyw teatru lalkowego jest jednym z wielu wcieleń, rozpowszechnionego dzięki tekstom Schopenhauera, symbolicznego rozumienia teatru jako alegorii ludzkiego życia i ludzkiego życia jako teatralnego przedstawienia. Każdy musi grać w wielkim teatrze kukiełkowym świata i czuć nitki, które nim sterują (Schopenhauer 420). Ulgę przynosi filozofia, która daje widok na cały teatr. Dzięki niej człowiek na jakiś czas przestaje być tylko aktorem, a staje się także widzem. Oczywistością jest, że patrząc na przedstawienie, staje się widzem. W tym jednak wypadku staje się takim widzem, który zdaje sobie sprawę z tego, że sam także jest częścią przedstawienia, że i na niego z kolei może patrzeć ktoś, kto obserwuje świat z jeszcze szerszej perspektywy (Schopenhauer 420).

Czy będą to Pochodnie Nerona, Sąd Parysa czy Taniec wśród mieczów na obrazie namalowany jest zarówno spektakl, jak i oglądająca go publiczność. Stojący przed płótnem Siemiradzkiego widz staje się kolejnym ogniwem tej konstrukcji. Artysta w różnych wariantach wielokrotnie powracał do tego samego schematu. Paradoksalność takiego ujęcia polega na tym, że z jednej 
strony buduje ono dystans między widzem a rozgrywającym się na jego oczach spektaklem, stawiając go za plecami namalowanej publiczności, a $\mathrm{z}$ drugiej strony wciąga go $\mathrm{w}$ obręb przedstawionej sceny jako kolejnego widza. W przypadku kurtyny mamy do czynienia $\mathrm{z}$ prawdziwym teatrem i prawdziwymi aktorami, a usytuowany pomiędzy widownią a sceną obraz można zinterpretować jako swego rodzaju parabasis. Ten stosowany od czasów Arystofanesa zabieg, zaadaptowany dla potrzeb dziewiętnastowiecznego teatru, polegał na tym, że aktor przechodził na proscenium i zwracał się bezpośrednio do widzów. W ten sposób przesuwał granice fikcji poza ramę sceny, a jednocześnie włączał widzów w obręb teatralnego przedstawienia. Taka konstrukcja wprowadzała szczególny rodzaj gry między prawdą i złudzeniem - kwestionowała znaczenie ramy scenicznej, a jednocześnie uświadamiała jej istnienie. Rozumiana jako odrębny gatunek malarski kurtyna teatralna jest parabasis par excellence, przedstawieniem, które w całości mieści się wewnątrz różnicy pomiędzy światem realnym i wyobrażonym.

Dla Siemiradzkiego niezwykle ważną rolę odgrywały strategie, które pozwalały mu występować w roli reżysera konstruującego spektakl, zachowującego emocjonalny dystans i produkującego złudzenia, które miały oszałamiać, ale jednocześnie dawać poczucie kontroli. Pozwalały zachować silne ego zarówno po stronie artysty, jak i po stronie widza. Częścią gry między złudzeniem i prawdą jest iluzjonistyczna dosłowność przedstawianych postaci i przedmiotów. Także przestrzeń namalowanego na kurtynie obrazu została określona jasno i wyraźnie. Kompozycja - z punktem zbiegu w centrum, podkreślona osią, dwoma symetrycznymi, antytetycznie skontrastowanymi grupami figuralnymi po dwóch stronach i portykiem zamykającym widok - zapewnia poczucie całkowitej kontroli. Niepewność co do ontologicznego statusu obrazu w połączeniu z wyjątkowo jasno zdefiniowanymi relacjami przestrzennymi i iluzjonistyczną wirtuozerią jest zaburzeniem, pęknięciem jedności przedstawienia, daje efekt dysonansu poznawczego i budzi niepokój.

Kolejna sprzeczność pojawia się między deklarowanym przekonaniem o decydującym znaczeniu poetyckiego natchnienia, boskiej inspiracji w procesie twórczym, a jednocześnie bardzo mocno zracjonalizowanym faktycznym procesem podejmowania decyzji ikonograficznych i formalnych. Centralną postacią, kulminacją całej kompozycji, jest Natchnienie - uskrzydlony młodzieniec w wieńcu laurowym, który zasiada w eksedrze „przybytku Apollina" i łączy Piękno z Prawdą, wyciągając ręce nad ich głowami. W przypadku tej figury inspiracją dla Siemiradzkiego była alegoria Poezji ze skle- 
pienia watykańskiej Stanza della Segnatura. Rycinę przedstawiającą tę postać (il. 4) umieszczono w słowniku mitologicznym Dizionario d'ogni mitologia ed antichità, który znajdował się w pracowni artysty w czasie, kiedy malował krakowską kurtynę. Wiemy o tym dzięki spisowi książek, który syn artysty, Bolesław, sporządził w październiku 1894 r. (Biblioteka książąt Czartoryskich, Kraków rkps MNK 1588). Źródłem natchnienia dla Siemiradzkiego nie było z pewnością poetyckie szaleństwo. Element nieświadomego działania był ograniczony do minimum. Proces twórczy polegał raczej na wyborze elementów ikonograficznych z repertuaru, którego dostarczał słownik mitologiczny. Siemiradzki nie potrzebował tragedii Eurypidesa ani poematów Homera. Ważne było wybranie stosownych do okoliczności zamówienia postaci i ich ikonograficznych układów. Inwencja koncentrowała się na przekształceniach i łączeniu gotowych elementów. Dzięki temu, jak w kalejdoskopie, powstawały nowe układy, chociaż składające się ze znanych elementów. Zmediatyzowane w naukowym opracowaniu słownika mity pozwalały nie angażować własnych emocji. Ten dystans pomagał zapewne sprawnie i na czas zrealizować zamówienie.

Z renesansowego wzoru Siemiradzki wziął układ ciała i gest. W oryginalnej wersji kobieca, uskrzydlona figura wieszczącej Poezji siedzi między dwoma puttami trzymającymi tablice $\mathrm{z}$ napisem numine afflatur. Te słowa nawiązują do natchnionej boską mocą kapłanki Apolla - Sybilli z VI księgi Eneidy Wergiliusza (,adflata est numine quando / iam propriore dei” 6.5051), księgi opisującej podróż Eneasza w zaświaty. Interpretacja Siemiradzkiego pozostawiała engram, układ będący zapisem potrzebnych w tym miejscu emocji i jednocześnie widmowy ślad kiedyś istotnych treści. Tak też odczytywano przesłanie, które niosła z sobą inspirowana przez Poezję Rafaela figura Natchnienia. Recenzent Kraju pisał: „Główną postacią jest tu Natchnienie, uosabiające nadprzyrodzone źródło sztuki, pojętej nie jako owoc refleksji, ale raczej jako skutek łaski." (Kraj, nr 13, 1894, s. 19). W kontekście dziewiętnastowiecznego Nachleben było to też wyraźne nawiązanie do antyku schrystianizowanego - oczywiste w kontekście watykańskiej Stanza della Segnatura i Wergiliusza, który jako anima naturaliter Christiana w Czwartej Eklodze miał zapowiadać przyjście na świat Chrystusa. Trudno przeoczyć sprzeczność między przyjętą w ikonografii obydwu kurtyn kluczową rolą przypisaną boskiemu natchnieniu i praktyką konstruowania postaci z elementów znalezionych w słowniku mitologicznym. Artysta unikał dosłownego, zbyt ewidentnego powtarzania oczywistych formuł. Tradycję ikonograficzną traktował jako rezerwuar swobodnie przekształcanych 
motywów. Często konstruował własne alegorie. Wybierał gesty, układ ciała, atrybuty postaci mitologicznych kojarzących się z pojęciem, które chciał przedstawić. W rezultacie powstawały eklektyczne figury, które często wywołują wrażenie dejà vu, mimo pozornie nowych rozwiązań.

Chociaż tematem najczęściej wykorzystywanym do dekoracji kurtyn teatralnych był Parnas - Apollo i Muzy - i chociaż faktycznie ten właśnie temat stał się ramą dla koncepcji Siemiradzkiego, artysta nie skorzystał z inspiracji Parnasu Rafaela ze Stanza della Segnatura, ale nawiązał do jednej z czterech alegorycznych figur znajdujących się na sklepieniu nad nim - do alegorii Poezji. Ze Stanza della Segnatura zapewne pochodzi także inspiracja dla groteskowych motywów dekoracyjnych, które na krakowskiej kurtynie wypełniają szczelnie architektoniczne płyciny „przybytku Apolla”.

Wyjątkowym przypadkiem jest postać Trefnisia. Na pierwszym planie, obok personifikacji Komedii, została przedstawiona postać, która początkowo w opisach była określana jako Momos. W późniejszych wersjach objaśnień zamiast znanego z Teogonii Hezjoda, ale też z humorystycznych pism i teatrzyków rewiowych, bóstwa ironii i sarkazmu pojawia się Trefniś. Jego kostium składa się z błazeńskiej czapki z dzwonkami, nagiego „antycznego" torsu i fragmentu draperii, spod której wystają krótkie spodenki ze wzorem w kolorowe romby, typowym dla stroju Arlekina. Trefniś bawi się marionetkami. Na pierwszym planie, w środkowej części kurtyny antyczna maska Komedii spotyka się z lalkami przedstawiającymi bohaterów współczesnego repertuaru teatru. Najwyraźniej Siemiradzki nie czuł się skrępowany tego rodzaju niekonsekwencjami. Warto zauważyć też, że Eros zjawia się na kurtynie dwa razy. Na pierwszym planie, po lewej stronie obrazu „płacze nad prochami drogiego serca”, a w centralnej części kurtyny wychyla się zza personifikacji Piękna. W Objaśnieniu ta druga postać została pominięta.

Siemiradzki zdecydował się na przedstawienie o alegorycznym, nie mitologicznym charakterze, jakkolwiek niewyraźne granice między tymi gatunkami nastręczały mu pewnych problemów. W całej swojej twórczości konsekwentnie unikał przedstawień mitologicznych. Jeżeli na jego płótnach pojawiają się jakieś antyczne bóstwa, to zawsze w nawiasie - wyłącznie jako posągi, płaskorzeźby lub aktorzy grający w przedstawieniu. Sąd Parysa (1892) ma podtytuł Pantomima na tarasie pałacu rzymskiego dostojnika i oprócz mitologicznego spektaklu pokazuje oglądających go widzów. Objaśnienia do kurtyn pomijają imiona Muz. Na przykład zamiast Melpomeny i Talii są „alegoryczne postacie Tragedii i Komedii.” Jedyna wymieniona 
w Objaśnieniu po imieniu Muza, Terpsychora, jest posągiem, który „otacza w tańcu grono młodzieży". Chociaż punktem wyjścia dla ikonografii obydwu kurtyn był temat Apollo i Muzy, to w obydwu przypadkach odwołaniem do Apolla są tylko motywy dekoracyjne (lira, głowa w promienistym nimbie) oraz rzeźby przedstawiające jego atrybuty (gryfy i delfin) w przypadku krakowskiej zasłony, a w przypadku lwowskiej - płaskorzeźbiony medalion. Znowu artysta sygnalizuje dystans - tym razem do mitologicznych postaci. Znowu też pojawia się figura reprezentacji reprezentacji - obrazu w obrazie, obrazu, na którym został przedstawiony motyw płaskorzeźby czy wolno stojącej rzeźby z postaciami nieobecnych bóstw.

Wydaje sie, że lekturą, która wpłynęła na stosunek Siemiradzkiego do mitologii, była książka Stéphane'a Mallarmé Les Dieux antiques. Nouvelle mythologie illustré d'après George $W$. Cox et les travaux de la science moderne, à l'usage des lycées, pensionnats, écoles et des gens du monde. Siemiradzki miał ją w swojej bibliotece w czasie, kiedy pracował nad kurtyną. W spisie zanotowana została jako pozycja 57, znajdująca się na V półce szafy pracownianej między Biblią a Storia della città di Roma Gregoroviusa.

Dokonana przez Mallarmégo trawestacja angielskiej pracy George'a W. Coxa przedstawiała pochodzące $\mathrm{z}$ wszystkich kultur postacie mitologiczne jako personifikacje sił natury, które ludzie „nie wiedząc prawie nic o sobie, ani o rzeczach, których doświadczali" (Mallarmé IX), wyobrażali sobie na swój obraz i podobieństwo. Mitologia nowoczesna miała uwolnić bóstwa od „resztek nieziemskiego blasku” i przedstawić je w taki sposób, żeby z powrotem „rozpłynęły się w naturalnych zjawiskach, od których pochodziły” (2). Reprodukcje starożytnych rzeźb czy malowideł przedstawiających bóstwa miały służyć przede wszystkim zwiększeniu atrakcyjności książki, a z drugiej strony „utrwalić wizerunki bogów przed ich zniknięciem” (X). Ryciny były „mitami ucieleśnionymi przez sztukę” (X), natomiast tekst operował „mitami wyjaśnionymi przez naukę” (X). Nie chodziło jednak o przeciwstawianie sobie tych ujęć. Wizerunki starożytnych bogów są „,całkowicie dekoracyjne i ornamentalne" (X) i jako takie zyskują prawo bytu. Wydaje się, że taki sposób myślenia był bliski Siemiradzkiemu.

Mityczne symbole zostały pozbawione przez Naukę baśniowych postaci, w których zamknęła je Starożytność. Oczom czytelnika, który właśnie kończy przeglądać tę książkę nie pozostaje nic poza wizerunkami bogów na zawsze ucieleśnionymi w marmurze, zanim ich znaczenie zredukowane zostało do światła, chmur, powietrza. (281) 
Stąd można zapewne wywieść zwyczaj malarza, który bogów antycznych przedstawiał wyłącznie jako „mity ucieleśnione przez sztukę” - jako płaskorzeźby, posągi czy malowidła.

Konsekwencją lektury Les Dieux antiques Mallarmégo jest zapewne także nietypowe przedstawienie Sfinksa, u którego stóp „walczą pierwiastki Dobrego i Złego", a nad nimi widoczna jest przecinająca niebo błyskawica. To wyobrażenie zawiera motywy obecne w tekście Mallarmégo, który płynnie łączy mitologię egipską, grecką i indyjską. W jednym akapicie można tam znaleźć Sfinksa, błyskawicę i postacie hinduskich bóstw symbolizujące walkę dobra ze złem oraz ich naukową interpretację jako personifikacji sił przyrody. Czytamy, że tajemnicę Sfinksa symbolizował „ryk grzmotu”, który pozostawał dla ludzi niezrozumiały. Natomiast w śmierci Sfinksa widziano „Zwycięstwo Indry, który zabija swojego wroga Vritrę i natychmiast przynosi deszcz odmienionej ziemi" (185).

Mallarmé, podobnie jak podążający w tym względzie jego śladem Siemiradzki, pozostawia $\mathrm{z}$ mitologii wizerunki bogów traktowane jako dzieła sztuki. Pozostawia formę, pod którą nie kryje się już żadna metafizyka i żaden archetypiczny dramat. W szerszej perspektywie - wspólne im jest zainteresowanie syntaktyczną stroną świata. Poruszanie się przede wszystkim w warstwie słów czy form, dążenie do uwolnienia sztuki od metafizycznych zobowiązań. Siemiradzki w takim zestawieniu wydaje się zaskakująco nowoczesny, przez dążenie do redukcji znaczeń i do tego, co Heidegger nazywał odbóstwieniem (Entgötterung) - „stanem nierozstrzygania o Bogu i bogach" (Heidegger 68).

W przeciwieństwie do Mallarmégo jednak Siemiradzki nie szuka w formach tylko muzyczności, ale używa ich jako wygodnych żetonów, zastępujących pojęcia $\mathrm{w}$ intelektualnej układance. Malarz, który był jednocześnie absolwentem Wydziału Przyrodniczego Uniwersytetu w Charkowie, gdzie studiował w okresie największych triumfów pozytywizmu, ma nieograniczone zaufanie do nauki i poznawczej siły ludzkiego intelektu. Nie „rzuca kośćmi”, tylko buduje piramidę. Mallarmé, który pokazuje bezsilność dyskursywnego myślenia, odwołuje się do przypadku i absurdu (Markowski), jest zupełnie obcy Siemiradzkiemu. Jedyna chwila, kiedy artysta, nie zdając sobie z tego sprawy, zbliża się do niego, to chwila, kiedy układa rebusy.

Siemiradzki myśli o sobie jako o podmiocie, a jednocześnie stara się maksymalnie zdystansować od woluntarystycznych wizji subiektywności, które stają się obiegową monetą pod koniec XIX wieku. W jego przypadku jest to subiectum oparte na naukowości, na naukowości budującej dystans 
między obserwatorem a obiektem. „Byt został uprzedmiotowiony w przedstawieniu, które dąży do tego, by wszelki byt 'ustawić' lub 'przedstawić' przed podmiotem" (Gielarowski 60). Siemiradzki, który na dwóch kurtynach maluje ołtarze Apolla, wydaje się dobrym przykładem człowieka „uwikłanego w zasłonę Mai”.

Narodziny tragedii Fryderyka Nietzschego dotyczą, zgodnie z tytułem, początków tragedii greckiej, książka ta jednak była pisana wobec współczesności - wobec opery Wagnera, ale także, można przypuszczać, wobec współczesnych obrazów. Przynajmniej w pierwszej części Narodzin tragedii Apollo, bóg plastyki i pięknego pozoru, jest niezbędnym dopełnieniem dionizyjskiego żywiołu muzyki. Nietzsche określa go jako „wspaniały boski obraz principii individuationis, z którego ruchów i spojrzeń przemawia do nas cała radość i mądrość 'pozoru', wraz z jego pięknością" (Nietzsche 24) Pisze o człowieku „uwikłanym w zasłonę Mai” i cytuje Schopenhauera (Świat jako wola i przedstawienie t. I, 416): „Jak na rozszalałem, ze wszech stron nieograniczonem morzu, co wyjąc wznosi i zniża wód góry, żeglarz siedzi w łodzi, ufając słabej łupinie; tak, wśród świata udręki, siedzi spokojnie jednostka, oparta z ufnością o principium individuationis" (24). Zasada indywiduacji zapewniała piękne złudzenia oraz pozwalała mądrze i świadomie ukryć zarówno potworną grozę, jak też „rozkoszne zachwycenie wyzierające z głębi natury i człowieka" (21). Nietzsche pokazuje jednak także, jak niewiele potrzeba, aby używając apollińskiego światła rozumu i pięknego pozoru, zapomnieć o odczuciu prawdy i tragiczności świata.

„Gdyby ten człowiek rozumiał Aischylosa i miał na pamięci sceny gdzie Dariusza duch występuje, gdzie Xerxes rozpacza. - Czy też widział początkową scenę Prometeusza, gdy «geniusz śmierci» i «przemoc»przykuwają go do skały" - pisał Wyspiański o krakowskiej kurtynie w liście do Lucjana Rydla. (Wyspiański 280). Wyspiański nie krytykuje alegorii w ogóle, nie zajmuje go też odróżnianie alegorii od symbolu. Waldemar Okoń przytacza przykłady alegorycznych pomysłów samego Wyspiańskiego i zauważa, że „za mało uwagi zwraca się na alegoryzm autora Polonii” (Okoń 168). Zachwyt artysty budziły alegoryczne figury „geniusza śmierci” i „przemocy” z tragedii Ajschylosa, natomiast irytował go patos zdewaluowany do schematycznych póz i min. Wyspiański zarzucał konceptom Siemiradzkiego banalność: „wprost pudełkowe są rozwiązania takich pomysłów jak taniec, muzyka, poezja" (Wyspiański 280). Bardziej jeszcze niż tautologiczny charakter znaków (Taniec na kurtynie tańczy, Śpiew śpiewa, a Tragedia załamuje ręce) przeszkadzał mu brak emocji. Wydaje się, że krytycznej 
opinii Wyspiańskiego o alegorycznej kurtynie Siemiradzkiego nie da się wytłumaczyć wyłącznie rozczarowaniem związanym z niepowodzeniem w konkursie, chociaż tak interpretowali uwagi artysty współcześni: „Tutaj komukolwiek powtórzę moje zdanie, spojrzy na mnie bardzo niechętnie, jak na człowieka, który zazdrością powodowany gada" (281). Katarzyna Nowakowska-Sito reakcję Wyspiańskiego określała jako „symptomatyczną dla zasadniczych różnic widzenia antyku u schyłku ubiegłego wieku" (Nowakowska-Sito 104). Owe różnice nie sprowadzały się do antytetycznie ustawionej pary alegoria-symbol.

Podłożem dziewiętnastowiecznej estetyki była wolność symbolicznej działalności umysłu. Czy jest to jednak rzeczywista podstawa? Czy owa działalność symboliczna nie jest $\mathrm{w}$ istocie i dziś ograniczona pewną przetrwałą tradycją mityczno-alegoryczną? Jeśli zaś tak, to trzeba ponownie zrelatywizować przeciwieństwo symbolu i alegorii, które uprzedzeniom estetyki przeżycia wydawało się absolutne: trudno też będzie uznać za absolutne odróżnienie świadomości estetycznej od mitycznej. (Gadamer 131)

$\mathrm{Na}$ kurtynie lwowskiej trzy centralne figury zostały zidentyfikowane za pomocą odpowiadających każdej z nich napisów umieszczonych w kartuszach nad ich głowami. Siedząca na delfickim trójnogu Pytia została podpisana jako Inspiratio, po jednej stronie znalazła się Phantasia - unosząca się nad ziemią postać kobieca z barwnymi skrzydłami, po drugiej Sapientia przedstawiona jako połączenie ubranej w hełm Minerwy i wagi wziętej z alegorii Sprawiedliwości. Na plafonie w pałacu Zawiszy Siemiradzki przedstawił Mądrość jako kobiecą postać trzymającą tabliczkę z napisem „II + II = IV”. Wyspiański określa alegorie Siemiradzkiego jako „rebusowe” (Listy 279). Zwraca uwagę napięcie między deklarowanym przywiązaniem do rozumienia sztuki jako efektu działania nieświadomej, irracjonalnej siły i stałym przypominaniem o racjonalności czy wręcz kalkulacji jako niezbędnym elemencie twórczości. To napięcie między wieszczeniem i kalkulacją odpowiada widocznemu napięciu między obrazem i słowem.

W starożytnej Grecji do obszaru języka wyroczni i interpretacji mitów należało słowo „zagadka” (gr. aivı $\gamma \mu \alpha$ [aínigma] - zagadka, zagadkowe

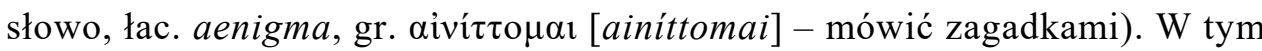
kontekście pojawia się również w literaturze filozoficznej. W Timajosie (Platon, Tim. 72b2) Widzący mówią, że ich zagadkowe słowa należy przetłumaczyć na zwykły język. Zadanie interpretacji spoczywa na prorokach. Aby zinterpretować zagadki, potrzebny jest specjalny dar, pozwalający zoba- 
czyć, co kryje się za tym, co poznawalne zmysłowo. Ci, którzy mają ten dar, jak Lynkeus, mogą dostrzec prawdziwą rzeczywistość stojącą za rzeczami (Plotyn, Enn. V, 8 (31) 4, 25). W retoryce termin aenigma był używany na oznaczenie niejasnej (niedającej się przejrzeć na wylot) alegorii. (Quintilian, Inst. orat. VIII, 6, 52).

Cyceron mówi o alegorii jako o ciągu metafor (Cicero, Orator 94). U Kwintyliana także znajdziemy określenie alegorii jako rozwiniętej metafory. I chociaż wciąż trwają dyskusje nad tym, jaki model metafory należy przyjąć, to istnieje już powszechna zgoda co do tego, że definicje metafory, które czynią z niej jedynie dekoracyjny element języka, słowne opakowanie, które jest dodawane dopiero po tym, kiedy poważne kwestie znaczenia zostały już załatwione, po prostu nie odpowiadają temu, w jaki sposob faktycznie metafora jest używana (Boys-Stones 3). Charakterystyczną tendencją w studiach poświęconych klasycznej tradycji metafory jest obecnie odwrót od teorii retorycznej, będącej źródłem późniejszej zachodniej tradycji, na rzecz Arystotelesa. „Klasyczne” definicje metafory opierają się przede wszystkim na antycznych podręcznikach retoryki, a więc na zaskakująco ograniczonej liczbie tekstów. Przy tym sami retorzy zachęcali do tego, aby ich ujęcie sytuować w ramach szerszego kontekstu myślowego, wskazując na alegorię jako na formę metafory.

Słowo „alegoria” (gr. $\grave{\lambda} \lambda \lambda \eta \gamma o \rho i ́ \alpha$ [allēgoría]) nie jest potwierdzone przed I wiekiem p.n.e. i zapewne stworzone zostało na użytek retoryki. Samo jednak pojęcie wywodzi się prawdopodobnie $\mathrm{z}$ dawnej praktyki poetów. Odnosiło się ono do alegorezy - egzegetycznej metody, która upatrywała głębszego znaczenia w tekstach, które wydawały się „mówić coś innego". Ważnym punktem odniesienia są więc teksty filozoficzne, które traktują alegorię zupełnie inaczej niż tradycja retoryczna, widząca w niej jedynie dekorację. $Z$ tego punktu widzenia jest oczywiste, że istnieją takie treści, których nie da się wyrazić inaczej jak tylko przez alegorię.

Retorzy mówią o alegorii jedynie w odniesieniu do potrzeb mówcy. Jego kunszt polega na umiejętności powiedzenia tego samego w różny sposób, przy użyciu różnych stylów, tak, aby ta sama treść była atrakcyjna dla dowolnej publiczności; na umiejętności dostosowania wyglądu argumentacji do konkretnych okoliczności bez zmiany istoty treści. Natomiast pomyślenie o alegorii w kategoriach metafory pozwala połączyć retorykę z filozofią.

Siemiradzki na obydwu kurtynach w centralnym punkcie umieścił nawiedzone przez Apolla postacie Natchnienia: mówiącą zagadkami Pytię w przypadku zasłony lwowskiej i postać inspirowaną alegorią Poezji Rafaela 
w przypadku zasłony krakowskiej. Wbrew jednak tradycji natchnionej poezji, do której się odwoływał, dążył do ograniczenia w swojej pracy roli wszelkich impulsów niepodlegających kontroli rozumu. Konstruując alegorie, często dosłownie przekładał słowa na obrazy. I tak, na przykład, jeśli zgodnie z akademicką doktryną „Piękno wyższe jest od Prawdy”, to Prawda siedzi, a Piękno stoi (co czyni je wyższym od Prawdy). Jeśli Eros płacze nad prochami serca, to na urnie można przeczytać napis: cordis cineri pax (pokój prochom serca). Jeśli Psyche „uwalnia się z więzów zmysłowości, usiłując za Muzyką i Śpiewem wznieść się ku niebu", to z jednej strony ciągną ją w dół młodzieńcy jednoznacznie skojarzeni $\mathrm{z}$ „więzami zmysłowości” przez dionizyjskie atrybuty (lamparcią skórę, dzban, wieńce z kwiatów i winnej latorośli), a $\mathrm{z}$ drugiej strony w górę pociąga ją za sobą Muzyka trzymająca lirę i śpiewający Śpiew. Trudno w tych pomysłach dopatrzeć się mocy boskiego Natchnienia czy jakiejś zagadki. Widać raczej tzw. zdrowy rozsądek. Widać też, że alegorie Siemiradzkiego bliższe są metonimii niż metaforze.

Dominujący po lewej stronie kurtyny Sfinks jest symbolem samego symbolizowania (Hegel 572), odsyła też do metafory hieroglifu. Hegel wielokrotnie powtarzał, że religia egipska jest stadium przejściowym między religiami natury i religiami ducha. Przeciwstawiał religię egipską jako religię tajemnicy religii greckiej, którą uważał za otwartą i transparentną. Przypominał Sfinksa, symboliczne przedstawienie Egiptu, i zwycięstwo mądrego Greka Edypa, który rozwiązał zagadkę, dając racjonalne wyjaśnienie dziwacznego wyobrażenia.

Zaprzyjaźniony z Siemiradzkim naukowiec i wynalazca Julian Ochorowicz pisał o rozszyfrowaniu hieroglifów przez Champolliona:

Przeszkadzało mu jeszcze panujące przekonanie, że hieroglify są pismem ideograficznem, lecz skoro raz przypuścił, że owe figury tajemnicze są wyobrażeniem dźwięków, nie zaś przedmiotów (...), błyskawica oświetliła jego umysł: hieroglify, od paru tysięcy lat milczące, przemówiły. (...) Czytelnik przeglądający dziś tygodnik z rebusami nie domyślał się zapewne, że miał przed sobą objaw szczątkowy pisma świętego kapłanów egipskich ... I istotnie, określimy najlepiej hieroglify, mówiąc, że było to pismo rebusowe. (Ochorowicz 29)

Język alegoryczny Siemiradzkiego, w typowy dla epoki sposób, a w przeciwieństwie do dziwactw Ikonologii Ripy, był oddzielony zupełnie od myślenia o tajemnicy. Z dzisiejszego punktu widzenia zarówno kategoryczne przekonanie o niemisteryjnym, wyłącznie racjonalnym charakterze religii greckiej, podobnie jak przekonanie o liniowym rozwoju pisma egipskiego 
od niejasnych obrazów do zapisu literowego, jest bardzo daleko idącym uproszczeniem (Vernus). Także rebusy nie są prostym przekładem dźwięków na obrazki, ale skomplikowanym, wykorzystującym różne modalności zapisem, w którym na pierwszym planie znajduje się sposób notacji, kosztem wyraźnie drugorzędnej treści (Brisset, Dumora i Simon-Oikawa).

W krakowskim Muzeum Narodowym, obok innych ofiarowanych przez rodzinę Siemiradzkiego pamiątek, są przechowywane szkicowniki z rebusami. Była to najwyraźniej jedna z ulubionych rozrywek artysty. Obfitość materiału pozwala na zorientowanie się w metodzie ich konstruowania. $\mathrm{O}$ ile jego alegorie są aż za bardzo proste i zrozumiałe, rebusy są wyjątkowo skomplikowane. Zaszyfrowane hasła są trywialne, ale też bardzo nieoczywiste. Na szczęście do niektórych zagadek zachowały się rozwiązania. Na przykład pierwsze z listy zapisanych rozwiązań brzmi: „Lepszy cietrzew na zębie, niźli mydło po obiedzie". Często w jednym zdaniu wykorzystywane są słowa w różnych językach (polski, włoski, francuski, czasem łacina). Na przykład rebus, którego rozwiązaniem jest powiedzonko „kasza pociecha nasza” (il. 5) składa się z litery „K(a)”, rysunku kapelusza z napisem en français - czyli chapeau (fonetycznie sza-po), dopisanej sylaby „ci”, i rysunku przedstawiającego człowieka wywołującego w górach „echa”. Na końcu dopisano wyraz „,nasza”. Odgadywanie wymaga także dosyć dużej erudycji - świat mitologiczny i elementy tradycji antycznej występują tu na równych prawach z zupełnie prozaicznymi przedmiotami. Warto zauważyć, że bogowie starożytni mają tutaj już tylko wartość fonetyczną. I tak na przykład rebus nr 14 (il. 6), którego rozwiązaniem jest zdanie: „Taras wiele uroku dodał pokojowi jadalnemu" oprócz końskiego uda (urok-u do-dał) ilustrują także przedstawienia starożytnego ołtarza (t-ara-s) i boginii Pokoju (pokoj-owi). Z kolei rozwiązaniem rebusu oznaczonego numerem 13 (il. 6) jest hasło: „Kiedy wisieć to za obie nogi”. Tutaj najbardziej interesującą częścią wydaje się ilustracja ostatniej części zdania - jest to doskonale znane $\mathrm{z}$ antycznej ikonografii bóstwo rzeczne, ale w ciepłej czapce i z napisem rzeka pótnocna. Jak się okazuje, chodzi o rzekę Ob. Na to przedstawienie nakłada się drugi motyw ikonograficzny - Saturna zjadającego swoje dzieci. Bóstwo rzeczne w czapce pożera bowiem jakieś nogi. Odczytujemy: Ob-jenogi, co fonetycznie odpowiada potrzebnej frazie: obie nogi. Nietrudno zauważyć, jak podczas swobodnej zabawy zaczyna działać nieświadomość. Figura okrutnego ojca w połączeniu syberyjską rzeką - takie nieocenzurowane odruchy wyobraźni zdarzały się Siemiradzkiemu wyłącznie na użytek domowy. Znaczenie obrazu ogranicza się na ogół do jego fonetycznej war- 
tości, bez względu na to, czy chodzi o przedstawienie Pokoju czy o przedstawienie kapelusza. Mitologia jest dla artysty tak samo naturalnym i niezbędnym obszarem rzeczywistości, jak przedmioty dnia codziennego. I podobnie jak one jest traktowana w sposób mechaniczny i eklektyczny motywy i postacie służą jako elementy układanki, w której stają się częściami zakodowanego hasła. Rebusy Siemiradzkiego wydają się naturalnym, kolejnym etapem racjonalizacji i formalizacji mitologicznego imaginarium. Właściwością rebusów jest to, że nie pozostawiają miejsca na żadne niejasności - mają tylko jedno prawidłowe rozwiązanie. Rebus zamienia obraz na słowo, słowo na dźwięki, dźwięki na litery. Tak dzieje się też z obrazami bóstw, które w rebusach Siemiradzkiego pojawiają się bardzo często - ulegają desemantyzacji. Obraz, ich widzialny znak, zostaje przełożony na dźwięk i zamieniony na litery. Ten proces przebiega jednak bardzo niekonsekwentnie. Jednocześnie można zauważyć początek odwrotnego zjawiska. Litery, ale i same głoski nabierają materialności, wchodzą ze sobą w związki przestrzenne, zyskują znaczenie. Na przykład słowo „wisieć” Siemiradzki uzyskał, rysując w monumentalnej literze i udrapowaną sieć. Obraz sieci potrzebny jest tylko jako sylaba wyrazu ,wisieć”. Natomiast litera odpowiadająca głosce „w” nigdzie fizycznie nie występuje i trzeba ją odczytać, rozpoznając, jak usytuowana jest sieć w stosunku do litery i. Czasem z kolei niewinna sylaba wywołuje lawinę prywatnych skojarzeń, nakładających się na mitologiczną ikonografię.

Rebus kwestionuje różnice między realnym i wyobrażonym, między materialnym i niematerialnym, między tym, co przeznaczone do czytania, i tym, co do oglądania, przekracza ustalone kategorie. Istotna jest właściwa zabawie swoboda i jednocześnie koncentracja na wyzwaniu technicznym, odwrócenie uwagi od znaczącego. Zadaniem jest zaszyfrowanie najbardziej banalnego hasła, ale za to w niezwykle wyrafinowany i różnorodny sposób. Uwaga układającego rebus koncentruje się więc na małych jednostkach sensu i na znaczących, uruchamiając jednocześnie wyparte w zwykłym trybie działania nieświadome treści - dzięki temu nieoczekiwanie pojawiają się ślady prywatnych emocji, wraca odczucie autentyczności. W miejscu, które wydaje się zupełnie jałowe, powstaje sens. 


\section{BIBLIOGRAFIA}

Boniecki, Edward. „Jak Henryk Siemiradzki malował kurtynę dla Teatru Miejskiego w Krakowie. Listy malarza do Konrada Wentzla". Pamiętnik Teatralny, nr 1, 2019, ss. 113-119.

Boys-Stones, George R. „Introduction”. Metaphor, Allegory, and the Classical Tradition. Ancient Thought and Modern Revisions, red. George R. Boys-Stones, Oxford University Press, 2003, ss. 1-5.

Sztuka Europy Wschodniej, t. V: Co znajduje się w obrazach Siemiradzkiego?, red. Jerzy Malinowski, Tako Publishing House, 2018.

Didi-Huberman, Georges. „Obraz jako rozdarcie i śmierć wcielonego Boga”. Tłum. Mirosław Loba, Artium Quaestiones, nr 10, 2000, ss. 229-303.

Dizionario d'ogni mitologia ed antichità, t. I-VI, red. Girolamo Pozzoli, Milano, Batelli e Fanfani, 1819-1824.

Gadamer, Hans-Georg. Prawda i metoda. Zarys hermeneutyki filozoficznej. Tłum. Bogdan Baran, Wydawnictwo Naukowe PWN, 2004.

Gielarowski, Andrzej. Kryzys kultury, kryzys człowieka. Fenomenologiczna krytyka kultury: Husserl, Lévinas, Henry. Wydawnictwo WAM, 2016.

Hegel, Georg Wilhelm Friedrich. Wyktady o estetyce. t. 1. Tłum Janusz Grabowski i Adam Landman, Państwowe Wydawnictwo Naukowe, 1964.

Heidegger, Martin. „Czas światoobrazu”. Drogi lasu. Tłum. Krzysztof Wolicki, Fundacja Aletheia, 1997, ss. 67-96.

Kraj, nr 13, 1894, s. 19.

Kuczyńska, Agnieszka. Malowane kurtyny teatralne Henryka Siemiradzkiego. Towarzystwo Naukowe KUL, 2010.

Mallarmé, Stéphane. Les Dieux antiques. Nouvelle mythologie illustrée d'après George W. Cox et les travaux de la science moderne à l'usage des lycées, pensionnats, écoles et des gens du monde. Paris, J. Rotschild, 1880.

Markowski, Michał Paweł. „Nicość i czcionka. Wprowadzenie do lektury „Rzutu kośćmi” Stéphane'a Mallarmé”. Stéphane Mallarmé. Rzut kośćmi nigdy nie zniesie przypadku. Tłum. Tomasz Różycki, Korporacja Ha!art, 2005, ss. 9-23.

Nietzsche Friedrich. Narodziny tragedii, czyli hellenizm i pesymizm [1872]. Tłum. Leopold Staff, J. Mortkowicz, 1907.

Nowakowska-Sito, Katarzyna. Między Wawelem a Akropolem. Antyk i mit w sztuce polskiej przetomu XIX i XX wieku. Historia pro Futuro, 1996.

Ochorowicz, Julian. Wiedza tajemna w Egipcie. Opowiadanie historyczno-przyrodnicze. Warszawa, Drukarnia Granowskiego i Sikorskiego, 1898.

Brisset, Claire-Akiko, Florence Dumora i Marianne Simon-Oikawa, redaktorzy. Rébus d'ici et d'ailleurs: écriture, image, signe. Maisonneuve \& Larose/hémisphère, 2018.

Okoń, Waldemar. Stygnąca planeta. Wydawnictwo Uniwersytetu Wrocławskiego, 2002.

Sarnecki, Zygmunt. „Henryk Siemiradzki. Szkic okolicznościowy”. Tygodnik Ilustrowany, nr 50, 1900, s. 992.

Schopenhauer, Arthur. W poszukiwaniu mąrości życia. Parerga i paralipomena, t. 2. Tłum. Jan Garewicz, Wydawnictwo Naukowe PWN, 2006.

Vernus, Pascal. „La naissance de l'écriture dans l'Égypte ancienne”. Archéo-Nil, nr 3, 1993: «Lectures de l'espace figuratif dans l'Égypte ancienne», ss. 75-108. 
Wyspiański, Stanisław. Listy zebrane, t. 2: Listy do Lucjana Rydla, red. Leon Płoszewski i Maria Rydlowa, cz. 1, Wydawnictwo Literackie, 1979, list z 6.03.1895, ss. 278-281.

„Spis książek Henryka Siemiradzkiego”, Biblioteka książąt Czartoryskich, rkps 1588.

\author{
KRAKOWSKA KURTYNA \\ HENRYKA SIEMIRADZKIEGO: ALEGORIE I REBUSY
}

Streszczenie

Przedmiotem artykułu jest namalowana przez Henryka Siemiradzkiego kurtyna Teatru Miejskiego (obecnie Teatru im. Juliusza Słowackiego) w Krakowie traktowana jako przykład szczególnej formuły malarstwa alegorycznego na swój sposób pokrewnej rebusom, które - jak świadczą liczne zachowane w szkicownikach przykłady $-\mathrm{z}$ upodobaniem uprawiał artysta. Zidentyfikowanie nowych źródeł ikonograficznych (przede wszystkim Les Dieux antiques Stéphane'a Mallarmé) i poszerzenie kontekstu dotychczasowych analiz pozwoliło na nowo postawić pytania o źródła twórczości i rolę wyobraźni w malarstwie późnoakademickim. Zestawienie alegorycznego programu kurtyny z konstruowanymi przez malarza rebusami (ze szkicowników zachowanych w Muzeum Narodowym w Krakowie) problematyzuje charakterystyczne dla epoki relacje między słowem a obrazem.

Słowa kluczowe: alegoria; rebus; kurtyna teatralna; Henryk Siemiradzki; malarstwo XIX wieku.

\title{
HENRYK SIEMIRADZKI'S CURTAIN IN KRAKÓW: ALLEGORIES AND REBUSES
}

Sum mary

This article focuses on the curtain installed in the Municipal Theatre in Kraków (now the Juliusz Słowacki Theatre) painted by Henryk Siemiradzki. The giant composition is an example of the unique formula of allegoric painting related to rebuses, which, as attested by the many drawings preserved in his sketchbooks, was the artist's favourite kind of pastime. The identification of new iconographic sources (primarily Les Dieux Antiques by Stéphane Mallarmé) and the broadening of the context for those already known has made it possible to ask questions anew about the sources of creativity and imagination in late academic painting. The juxtaposition of Siemiradzki's allegorical curtain manifesto with the rebuses he devised (contained in the sketchbooks preserved in the National Museum in Kraków) problematises the issue of the relationship between word and image which was characteristic of that period.

Keywords: allegory; rebus; theatre curtain; Henryk Siemiradzki; 19th-century painting. 


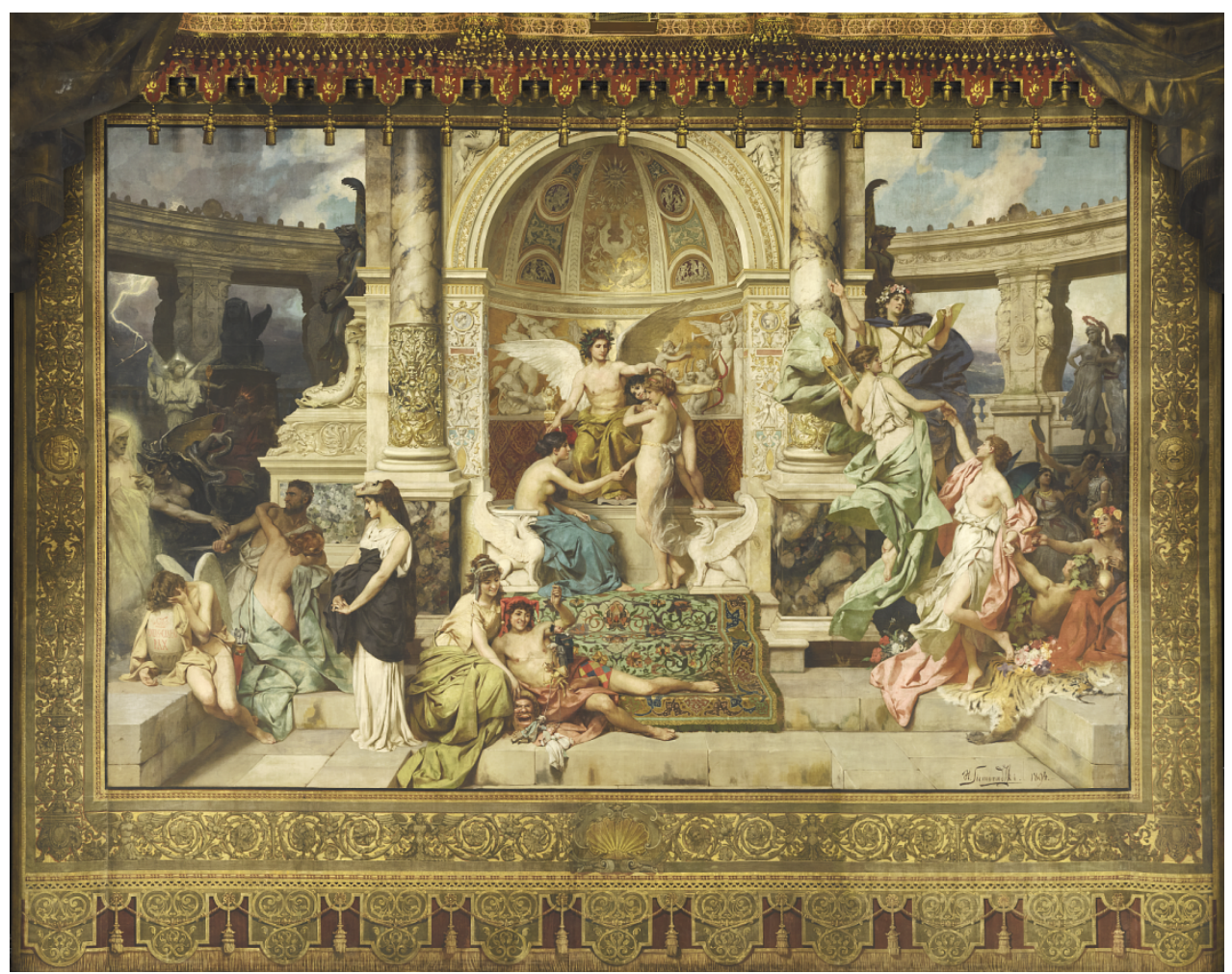

1. Henryk Siemiradzki, Kurtyna w Teatrze im. Juliusza Słowackiego w Krakowie. Właścicielem praw do wizerunku kurtyny jest Teatr im. Juliusza Słowackiego w Krakowie, a fotografią dysponuje Muzeum Narodowe w Krakowie.

Fot. Pracownia Fotograficzna Muzeum Narodowego w Krakowie. 


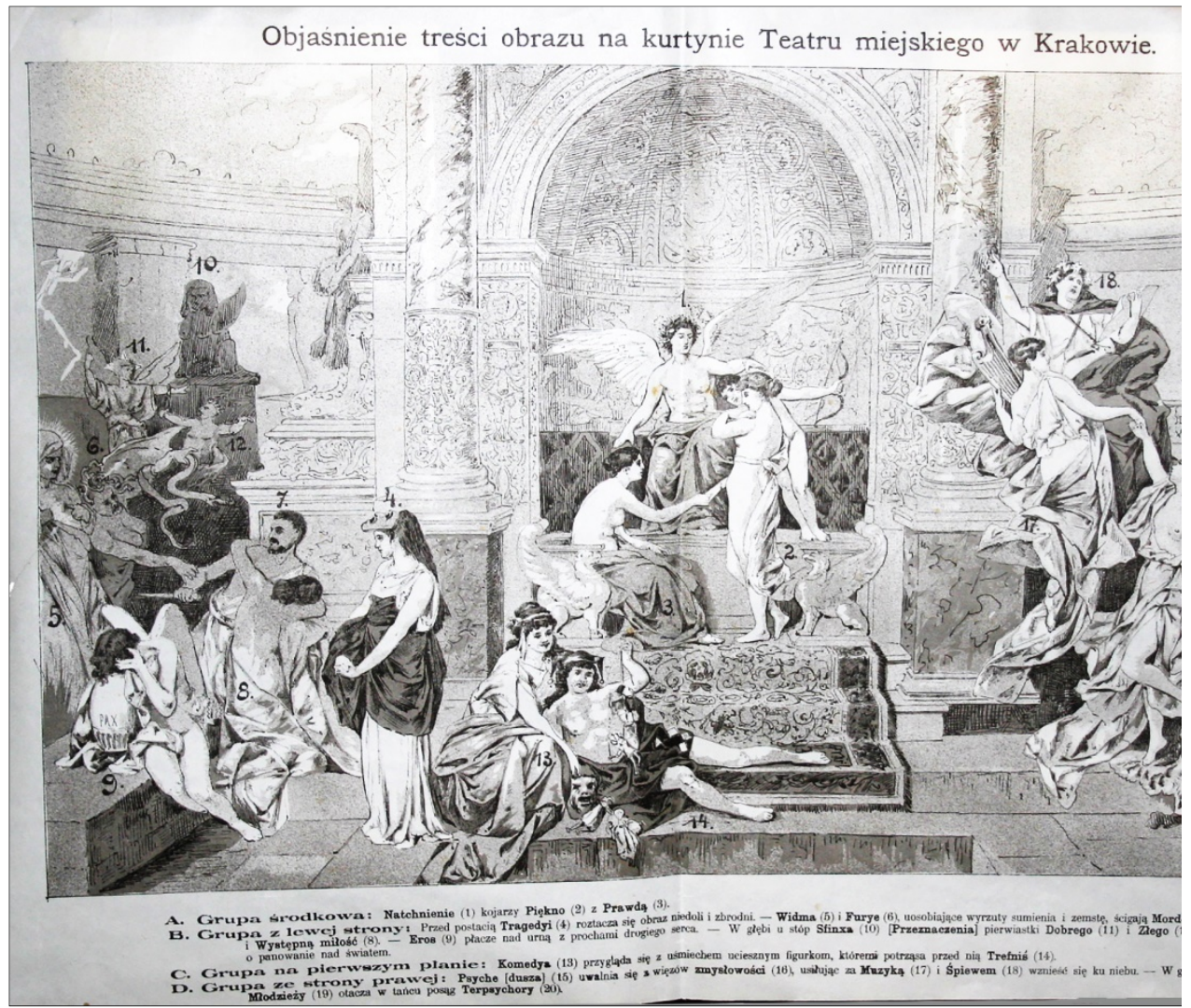

2. Objaśnienie treści obrazu na kurtynie Teatru miejskiego w Krakowie

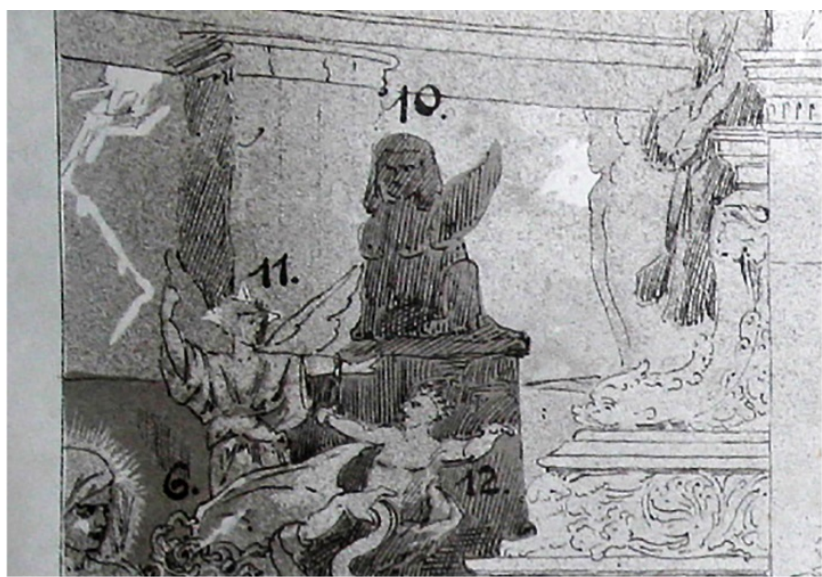

3. Objaśnienie treści obrazu na kurtynie, fragment 


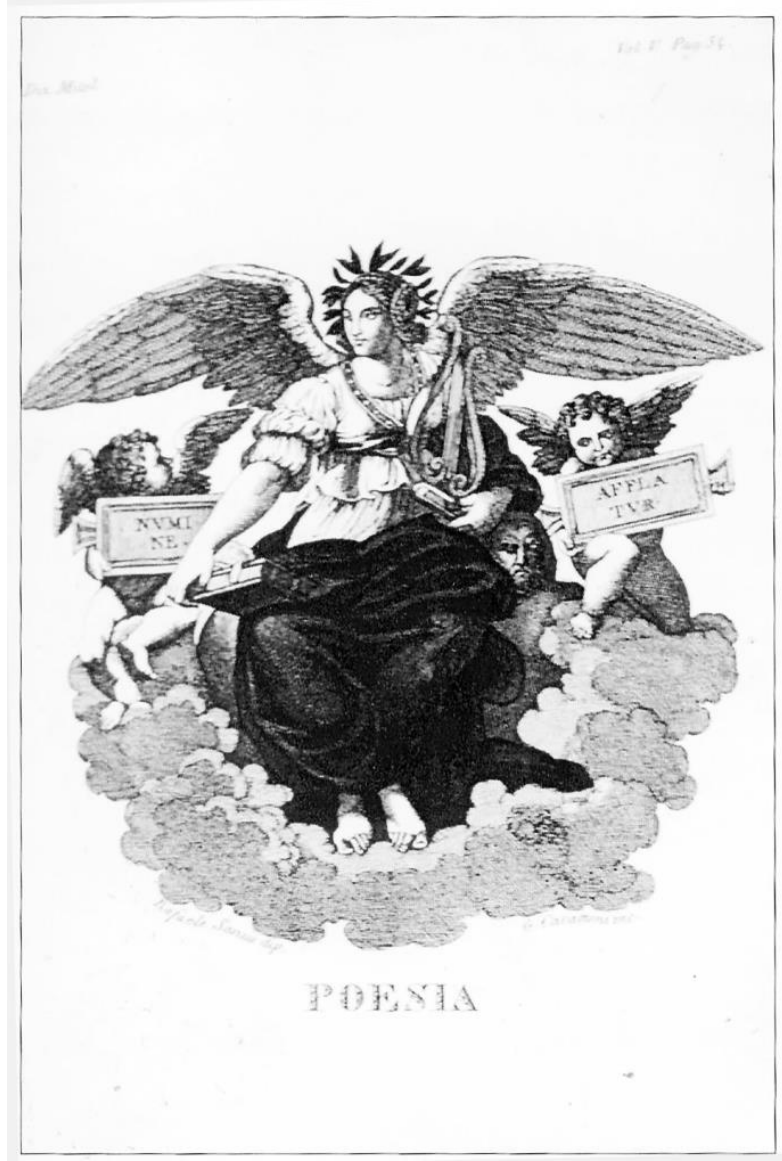

4. Figura Poezji. Rycina z Dizionario d'ogni mitologia ed antichità według polichromii Rafaela ze sklepienia Loggia della Segnatura 


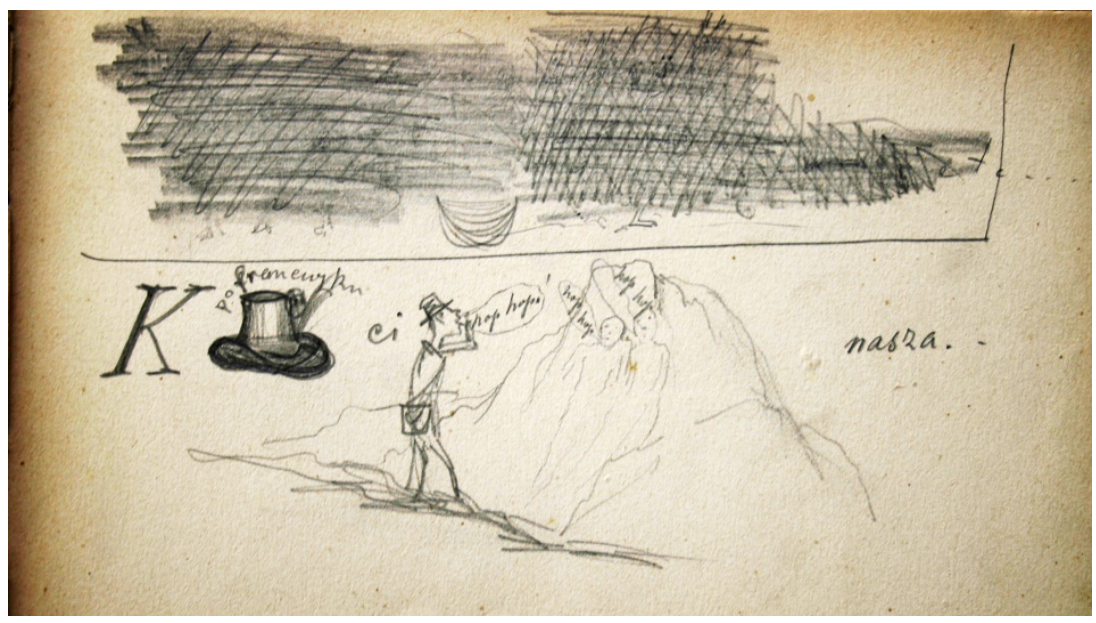

5. Henryk Siemiradzki, Rebus Kasza pociecha nasza, szkicownik MNK III-r. a-18395/9

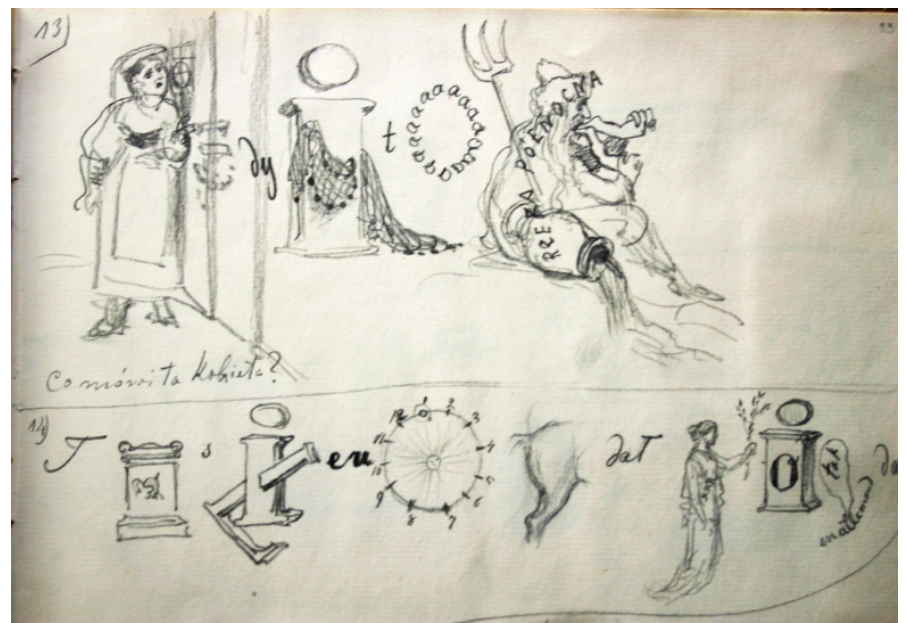

6. Henryka Siemiadzki, Rebus Kiedy wisieć, to za obie nogi, szkicownik MNK III-r. a-17692/33 